\title{
Combined Effect of IL-12Rß2 and IL-23R Expression on Prognosis of Patients with Laryngeal Cancer
}

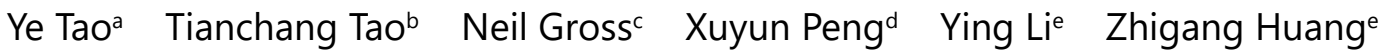 \\ Limei Liu $^{f}$ Guojun Lic,g Xiaohong Chen ${ }^{e}$ Jianming Yang ${ }^{d}$
}

\begin{abstract}
aDepartment of Otolaryngology-Head and Neck Surgery, The First Affiliated Hospital of Anhui Medical University, Hefei, ${ }^{\circ}$ Beijing Tongren Eye Center, Beijing Tongren hospital, Capital Medical University, Beijing Ophthalmology \& Visual Sciences Key Lab, Beijing, China, 'Department of Head and Neck Surgery, The University of Texas MD Anderson Cancer Center, Houston, USA, 'Department of Otolaryngology-Head and Neck Surgery, The Second Affiliated Hospital of Anhui Medical University, Hefei, eDepartment of Otolaryngology-Head and Neck Surgery, Key Laboratory of Otolaryngology Head and Neck Surgery, Beijing Tongren Hospital, Capital Medical University, Beijing, Key Laboratory of Otolaryngology, Head and Neck Surgery, Ministry of Education, Beijing Institute of Otolaryngology, Beijing fDepartment of Ophthalmology, Yuhuangding Hospital of Qingdao University, Yantai, China, 9Department of Epidemiology, The University of Texas MD Anderson Cancer Center, Houston, USA
\end{abstract}

\section{Key Words}

Tumor-infiltrating lymphocytes $\bullet$ Tumor microenvironment $\bullet$ Laryngeal cancer $\bullet$ Interleukin-23 receptor $\bullet$ Interleukin-12 $\beta 2$ receptor $\bullet$ Prognosis

\begin{abstract}
Background/Aims: This study aimed to pathologically elucidate the roles of interleukin-12 receptor (IL-12R) $\beta 2$ and interleukin-23 receptor (IL-23R) expression in tumor cells and tumorinfiltrating lymphocytes (TILs) in the tumor microenvironment and to determine their combined effect on prognosis of laryngeal cancer (LC). Methods:The tumor-cell expression scores and TIL positivity ratiosof IL-12Rß2 and IL-23R in matched LC and normal laryngeal tissue samples from $61 \mathrm{LC}$ patients were measured via immunohistochemistry $(\mathrm{IHC})$. We adopted a linear regression model to analyze the correlation between IL-12Rß2 and IL-23R expression in tumor cells and TIL ratios. TheKaplan-Meier log-rank test and Cox regression hazard ratios were used to analyze survival. Results: LC tumor cells had a higher IL-12R $\beta 2$ expression and TIL ratio than IL-23R expression and TIL ratio. The significant correlations between IL-12R 32 and IL-23R expression and TIL ratios were identified in LC tissues, particularly in well-differentiated LC. Furthermore, either high tumor cell IL-12R 32 or low IL-23R expression had better survival than its corresponding low or high expression, respectively. Similar results did for IL-12R $\beta 2$ ratio and IL-23R ratio. Finally, patients with both high IL-12R 32 and low IL-23R had the best prognosis among any other combined groups with both gene expression $(\mathrm{HR}, 0.1 ; 95 \% \mathrm{Cl}$,

Y. Tao, T. Tao and L. Liu contributed equally to this work.

Jianming Yang Dept. of Otolaryngology-Head and Neck Surgery, The Second Affiliated Hospital of Anhui Medical

and Xiaohong Chen University Hefei, 230061 Hefei; Dept. of Otolaryngology-Head and Neck Surgery, Beijing Tongren

Hospital, Capital Medical University, 100730 Beijng (China); E-Mail jmyang88@163.com; trchxh@163.com
\end{abstract}

\section{KARGER}




\section{Cellular Physiology Cell Physiol Biochem 2018;50:1041-1054 \begin{tabular}{ll|l} 
DOl: 10.1159/000494515 & (0) 2018 The Author(s). Published by S. Karger AG, Basel \\
www.karger.com/cpb
\end{tabular}}

Tao et al.: Opposing Roles of IL-12Rß2 and IL-23R in Laryngeal Cancer

0.0-0.8). Likewise, patients with positive ratios of high IL-12R 32 and low IL-23R TILs had the best survival (HR, 0.1; $95 \% \mathrm{Cl}, 0.0-0.4)$. Conclusion: IL-12Rß2 and IL-23R create a homeostasis within the tumor cells and TILs, and this homeostasis affects prognosis. While the intrinsic mechanisms of epigenetic immunoediting for IL-12Rß2 and IL-23R remain unknown, additional larger and functional studies are warranted for validation.

\section{Introduction}

In the United States, approximately 9, 500 patients are diagnosed every year with laryngeal cancer (LC) [1], and an estimated 26, 400 new laryngeal cancer cases and 14, 500 cancer deaths occurred in China in 2015 [2]. Tobacco carcinogens are the major risk factors and cause genetic and epigenetic damage in epithelial cells [3]. The accumulation of genetic aberrations and damage facilitates the epithelial-mesenchymal transition (EMT), in which cancer stem cells (CSCs) are thought to be the oncogenic derivatives of normal-tissue stem or progenitor cells in primary tumors at a very early stage of development [4].

When EMT has occurred and intrinsic tumor-suppressor mechanisms have failed, CSCs experience extrinsic pressure from tumor-infiltrating lymphocytes (TILs) $[5,6]$. The various laryngeal TILs interact with secreted cytokines in the tumor microenvironment and typically either kill tumors at early stages or promote tumors at advanced stages. Therefore, CSCs and TILs can form the 'three-E' sequential cancer immunoediting phases: elimination, equilibrium, and escape [5-8].

The equilibrium phase is mainly based on adaptive immunity through the $\mathrm{CD} 4^{+} \mathrm{T}$ helper (Th)1/Th2 cell paradigm [5, 7]. Th1 cells and their product interferon (IFN)- $\gamma$ are essential to maintain tumor cells in a state of functional dormancy, whereas Th2 cells stimulate CD4 ${ }^{+}$Tregs to block the anti-tumor activity of CD4 ${ }^{+} \mathrm{Th} 1$ and $\mathrm{CD} 8^{+} \mathrm{CTL}$ cells [9-11]. Moreover, in maintaining occult cancer cells in a state of immune-mediated dormancy, the opposing and critical roles of interleukin (IL)-12 and IL-23 have been identified in methylcholanthrene (MCA)-induced cancers [12].

IL-12 and IL-23 are related in structure, but distinct in function in maintaining immune equilibrium $[12,13]$. Structurally, IL-12 and IL-23 are heterodimeric cytokines that share a subunit, IL-12p40, and bind to a common receptor chain, IL-12 receptor (IL-12R) $\beta 1$ [14]. The IL-12R consists of IL-12R $\beta 1$ and IL-12R $\beta 2$, while IL-23 binds to a receptor composed of IL-12R $\beta 1$ and IL-23R [14]. Functionally, the IL-12/IL-12R axis promotes the differentiation of naive $\mathrm{CD}^{+} \mathrm{T}$ cells into IFN- $\gamma$-producing TH1 cells, whereas IL-23/IL-23R promotes the Th17 and Treg cell lineages. Th1 and Th17 productions are critical for maintaining immunity equilibrium, and therefore, Th17 and Treg dysregulation can lead to many autoimmune diseases [14-17].

In the tumor microenvironment, opposing roles on carcinogenesis have been identified for IL-12 and IL-23 [12,13]. In ovarian cancer, large quantities of CD8+ TILs and a high CD8+/ Treg cell ratio indicate favorable prognosis [18]. IL-12 can facilitate the tumor infiltration of CD8 ${ }^{+} \mathrm{T}$ cells, whereas IL-23 can reduce CD8 ${ }^{+} \mathrm{T}$ cells and promote Treg cells in the tumor, thereby enhancing tumor angiogenesis [13]. Furthermore, the IL-12 and IL-23 equilibrium can be disrupted by the over-activation of the transcription factor STAT3 [13, 19]. In tumorinfiltrating CD4 ${ }^{+} \mathrm{Foxp}^{+}{ }^{+}$T-regs, overactive STAT3 significantly upregulates IL-23R, and the IL23-driven IL-23R-STAT3 pathway can form a positive-feedback loop, thereby facilitating tumor growth $[13,20,21]$. Moreover, IL-23R blockade significantly reduces tumor growth in vivo $[13,20]$. In addition, overactive STAT3 can decrease IL-12 transcription and thereby reduce INF- $\gamma$ production [22], which in turn, can reduce IL-12R $\beta 2$ expression in human peripheral blood mononuclear cells (PBMCs) [23].

Likewise, opposing impacts on prognosis have been identified for IL-12R $\beta 2$ and IL23R expression in many tumor types. Patients with high IL-12R $\beta 2$ expression in colorectal [24], lung [25], and oral squamous cell [26] cancers have prolonged disease-free survival, whilepoor prognosis and promotion of tumor growth are associated with high IL-23R 
expression in lung [27], colorectal [28, 29], and oral [30] cancer cells. Furthermore, IL-12R $\beta 2$ is expressed significantly more frequently in stage-I tumors than in stage-II or -III tumors, suggesting that IL-12R $\beta 2$ downregulation is a tumor-escape mechanism [25]. In contrast, IL-23R is expressed in squamous cell carcinoma and non-small cell lung cancer cell lines via alternative splicing [31], and spliced isoforms of IL-23R can affect cancer cell response to IL23 [32], which may promote tumor growth [33].

In these previous studies,opposing roles of IL-12R $\beta 2$ and IL-23R were identified not only with regard to their tumor cell expression but also regarding their TIL ratios. Recently, we demonstrated that a high ratio of IL- $12 \mathrm{R} \beta 2^{+}$TILs $(\geq 0.35)$ in LC indicates a favorable prognosis [34], while a poor prognosis is potentially associated with a high ratio of IL-23R $\mathrm{R}^{+}$TILs (unpublished data). Therefore, we hypothesized that IL-12R $\beta 2$ and IL-23R may construct an immunological equilibrium within the tumor cells and TILs, respectively. Furthermore, this equilibrium may be associated with tumor cell differentiation, which may further modulate the tumor cell tumorigenicity and impact TILs within the tumor microenvironment, leading to divergent prognoses. These results may further help us to understand and stratify immunological parameters and provide a strong prognostic indicator.

\section{Materials and Methods}

\section{Patients and tissue samples}

All patients provided written informed consent for use of their tissue samples and information, and this study was approved by the institutional review board at the Anhui Medical University. After the clinical records of LC patients in a database at our institution were reviewed, 61 patients who underwent surgery with pathologically confirmed LC from 2008 to 2016 were enrolled. A consort flow diagram is presented in Fig. 1, in which the selection criteria and the eligibility assessment were executed. The patients had archived tumor samples and available data for a minimum follow-up of 36 months or until death. Tumor histological classification and differentiation grades were determined based on the 1999 World Health Organization histological classification standards for LC. Tumor staging was performed using the 2009 TNM staging criteria of the Union for International Cancer Control. According to the study protocol, posttreatment follow-up for all patients consisted of medical record monitoring and/or telephone interviews, and clinicopathological data were collected for all 61 patients (Table 1).

All tumor samples from the 61 patients contained more than $50 \%$ tumor cells and were stored at $-80^{\circ} \mathrm{C}$ until use. Paired LC and adjacent normal mucous membrane tissue samples were obtained. Adjacent normal tissue samples were obtained at least $5 \mathrm{~mm}$ from the tumor margins [35]. All 61 paired samples were used for IL-12R 32 and IL-23R expression assessment using immunohistochemistry (IHC).

\footnotetext{
Pathological review

Hematoxylin and eosin-stained slides containing paired frozen tumor and normal tissue sections were examined twice by pathologists to ensure that tumor samples with high-density cancer foci $(>75 \%)$ were used and that the normal tissue had no tumor components. All samples were independently reviewed by two pathologists, and disagreements were settled via discussion.
}

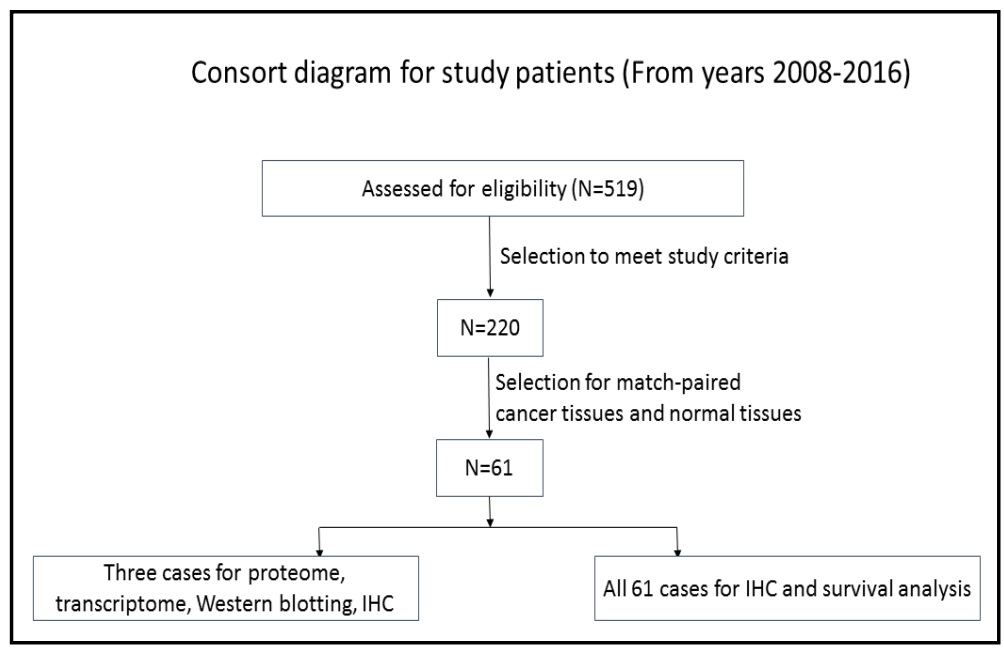

Fig. 1. Consort diagram for study patients (from 2008-2016). 


\section{Cellular Physiology Cell Physiol Biochem 2018;50:1041-1054 and Biochemistry \begin{tabular}{l|l} 
DOI: 10.1159/000494515 & (c) 2018 The Author(s). Published by S. Karger AG, Basel \\
www.karger.com/cpb
\end{tabular}}

Tao et al.: Opposing Roles of IL-12Rß2 and IL-23R in Laryngeal Cancer

Table 1. Clinicopathological characteristics of patients with LC

\begin{tabular}{|c|c|c|c|c|c|}
\hline \multirow{2}{*}{ Variable } & \multirow{2}{*}{ Total } & \multicolumn{3}{|c|}{ Cancer cell differentiation } & \multirow[b]{2}{*}{$\mathrm{P}$} \\
\hline & & Well-differentiated & Moderately- differentiated & Poorly-differentiated & \\
\hline Age, years & & & & & 0.069 \\
\hline$<60$ & 24 & 16 & 6 & 2 & \\
\hline$\geq 60$ & 37 & 14 & 20 & 3 & \\
\hline Sex & & & & & 0.504 \\
\hline Male & 60 & 30 & 25 & 5 & \\
\hline Female & 1 & 0 & 1 & 0 & \\
\hline Smoking & & & & & 0.817 \\
\hline Ever & 51 & 26 & 21 & 4 & \\
\hline Never & 10 & 4 & 5 & 1 & \\
\hline Alcohol & & & & & 0.867 \\
\hline Ever & 44 & 22 & 18 & 4 & \\
\hline Never & 17 & 8 & 8 & 1 & \\
\hline Primary tumor site & & & & & 0.172 \\
\hline Glottis & 32 & 19 & 9 & 4 & \\
\hline Superior glottis & 27 & 10 & 16 & 1 & \\
\hline Inferior glottis & 2 & 1 & 1 & 0 & \\
\hline TNM stage & & & & & 0.023 \\
\hline I or II & 42 & 25 & 13 & 4 & \\
\hline III or IV & 19 & 5 & 13 & 1 & \\
\hline
\end{tabular}

Table 2. IRS calculation. ${ }^{\text {a }}$ IRS range: $0-12$. ${ }^{\text {b }}$ Cut-off value: IRS=6; IRS<6: low-expression group; IRS $\geq 6$ : highexpression group

\begin{tabular}{lccc}
\hline $\begin{array}{l}\text { A (proportion of } \\
\text { positive cells) }\end{array}$ & B (intensity of immunostaining) & IRS (A×B) a & Expression group ${ }^{\mathrm{b}}$ \\
\hline $0=$ no positive cells & $0=$ no staining reaction & $0-1$ (grade 0) & Low-expression \\
$1=\leq 10 \%$ positive cells & $1=$ mild reaction $(+)$ & $2-4$ (grade 1) & \\
$2=11-50 \%$ positive cells & $2=$ moderate reaction $(++)$ & 6,8 (grade 2) & High-expression \\
$3=51-80 \%$ positive cells & $3=$ intense reaction $(+++)$ & 9,12 (grade 3) & \\
$4=>80 \%$ positive cells & & & \\
\hline
\end{tabular}

\section{Immunohistochemical staining for IL-12Rß2 andIL-23R}

IHC studies were performed using a streptavidin-biotin-peroxidase complex-based method [36]. Five-micrometer, formalin-fixed, paraffin-embedded tissue sections were deparaffinized in xylene and rehydrated with gradient concentrations of ethanol. Endogenous peroxidase activity in the pathological sections was blocked with $0.35 \% \mathrm{H}_{2} \mathrm{O}_{2}$ in phosphate-buffered saline. Antigens were retrieved by heating the sections in a 350-W scientific microwave for 5 minutes, and nonspecific binding in the sectionswas blocked with $1 \%$ bovine serum albumin in phosphate-buffered saline. Sections were stained with anti-IL23Rantibody (Abcam, Eugene, Oregon, U.S.) or anti-IL-12R 32 antibody (Abcam, Eugene, Oregon, U.S.) at a 1:500 dilution and visualized with a secondary antibody (EnVision; DakoCytomation, Glostrup, Denmark). The slides were then incubated with 3, 3'-diaminobenzidine chromogen (DakoCytomation), counterstained with Mayer's hematoxylin, and mounted with Aquatex (Merck, Darmstadt, Germany).

\section{Immunohistochemical staining intensity and immunoreactive score assessment}

Scoring of IHC staining intensity was performed according to the immunoreactive score (IRS) assessment [37, 38], which is a standardized protocol for the semiquantitative measurement of the expression of IHC markers on a wide spectrum. The IRS ranges from 0 to 12 as a product of multiplication of the positive-cell proportion score (0-4) and staining intensity score (0-3) (Table 2).Using this method, the IRS was calculated for IL-12R $\beta 2$ or IL-23R expression in LC samples.

TIL assessment and IL-12Rß2- or IL-23R-positive TIL ratio calculation

Using the method of TIL assessment described in a previous breast cancer study [39], the following criteria were used for the TIL calculation: 1) lymphocytes were counted in the highest lymphocyte-enriched areas in 10 consecutive high-power microscopic fields (magnification, 40×; field diameter, $490 \mu \mathrm{m}$ ), and 


\section{Cellular Physiology Cell Physiol Biochem 2018;50:1041-1054 \begin{tabular}{l|l|l} 
and Biochemistry Published online: 24 October 2018 & $\begin{array}{l}\text { ○ } 2018 \text { The Author(s). Published by S. Karger AG, Basel } \\
\text { www.karger.com/cpb }\end{array}$ \\
\hline
\end{tabular}}

Tao et al.: Opposing Roles of IL-12Rß2 and IL-23R in Laryngeal Cancer

Table 3. TIL ratio calculation and groups. ${ }^{\text {a: }}$ cut-off value: the median of ratio (35\%) of IL-12R $\beta 2^{+}$lymphocytes in adjacent normal tissues; ${ }^{\text {b. }}$ cut-off value: the median of ratio (30\%) of IL-23R ${ }^{+}$lymphocytes in adjacent normal tissues

\begin{tabular}{lcc}
\hline Ratio of positive cells & IL-12R $\beta 2$ groups a & IL-23R groups ${ }^{b}$ \\
\hline \multirow{2}{*}{ TIL ratio (positive TILs vs. overall TILs) } & High-ratio $(\geq 35 \%)$ & High-ratio $(\geq 30 \%)$ \\
& Low-ratio $(<35 \%)$ & Low-ratio $(<30 \%)$ \\
\hline
\end{tabular}

the results were averaged; 2) theIL- $12 \mathrm{R} \beta 2^{+}$or IL-23R ${ }^{+}$TIL ratio was calculated by dividing the number of IL-12R $\beta 2^{+}$or IL-23R $\mathrm{R}^{+}$TILs, respectively, by the total number of TILs; 3 ) the TILs within the borders of invasive tumors were evaluated; 4) the TILs in tumor zones with crush artifacts, necrosis, or regressive hyalinization as well as in previously obtained core biopsy sites were excluded from the final calculation; 5) all mononuclear cells (including lymphocytes and plasma cells) were scored, but polymorphonuclear leukocytes were not; 6 ) one section of sample tissue (4-5 $\mu \mathrm{m}$; magnification, 200-400x) per patient was considered to be sufficient for analysis; and 7) a pathologist fully assessed the average density of TILs in the tumor area without focusing on hot spots. For cut-off values, we adopted the median of ratio of IL-12R $\beta 2^{+}$ and IL-23R+ lymphocytes in adjacent normal tissues (Table 3).

\section{Statistical analyses}

The data are expressed as the mean \pm standard deviation. In tissue samples, clinicopathological characteristics and IL-12R $\beta 2$ and/or IL-23R expression were analyzed using the $\chi^{2}$ test. Differences in variables within groups (overall cases group; well-differentiated [WD] group;moderately and poorly differentiated [MPD] group) were compared using paired Student $t$-test. We adopted a linear regression model to analyze the correlation between IL-12R $\beta 2$ and IL-23R tumor cell expression and TIL ratios. The Kaplan-Meier log-rank test and Cox regression models were used to estimate overall survival in the 61 patients grouped for joint effects. Two-sided $p$ values less than 0.05 were considered significant. The data were analyzed using the SPSS 20.0 statistical software program (version 20.0; IBM Corporation, Armonk, NY, USA).

To group tumors based on IL-12R $\beta 2$ or IL-23R expression, consistent with a previous study, we used the median IRS value (tumor cell expression) as the cut-off value to separate the 61 patients into the lowand high-expression groups. With these cut-off values, we separated the 61 patients into IL-12R $\beta 2$ low(IRS $<6, n=22$ ) and high- (IRS $\geq 6, n=39$ ) expression groups and into IL-23R low- $(I R S<4, n=40)$ and high(IRS $\geq 4, n=21$ ) expression groups.

To group tumors based on IL-12R $\beta 2^{+}$or IL-23R ${ }^{+}$TIL ratios, consistent with a previous study, we used the median ratio of $\mathrm{IL}_{-}-12 \mathrm{R} \beta 2^{+}(35 \%)$ or $\mathrm{IL}^{-} 23 \mathrm{R}^{+}$lymphocytes $(30 \%)$ in adjacent normal tissues as the cutoff value. Using these cut-off values, we separated the 61 patients into IL-12R $\beta 2^{+}$high- (ratio $\geq 35 \%, n=24$ ) and low- (ratio $<35 \%, \mathrm{n}=37$ ) ratio groups and IL-23R $\mathrm{R}^{+}$high- (ratio $\geq 30 \%, \mathrm{n}=36$ ) and low- $($ ratio $<30 \%, \mathrm{n}=25$ ) ratio groups.

To evaluate joint effects of IL-12R 32 and IL-23R tumor cell expression, according to the respective anti-tumor and pro-tumor roles of IL-12R $\beta 2$ and IL-23, we separated the 61 patients into 3 groups as follows: patients with high IL-12R $\beta 2$ expression and low IL-23R expression $(n=21)$; patients with both high or both low IL-12R $\beta 2$ and IL-23R expression ( $\mathrm{n}=34)$; and patients with low IL-12R 32 expression and high IL-23R expression $(n=6)$. Likewise, to evaluate the joint effects of the IL-12R $\beta 2^{+}$and IL-23R $R^{+}$TIL ratios, we separated the 61 patients into 3 groups as follows: patients with a high IL-12R $\beta 2^{+}$ratio and low IL-23R ratio $(n=20)$; patients with high or low ratios of both IL-12R $\beta 2^{+}$and IL-23R $\mathrm{R}^{+}$TILs $(n=26)$; and patients with low IL-12R $\beta 2^{+}$ratios and high IL-23R ${ }^{+}$ratios $(n=15)$. 


\section{Results}

\section{Pathological characteristics of TIL ratios of IL-12Rß2 and IL-23R in tumors}

In theIHC analysis, IL-12R $\beta 2$ and IL-23Rimmunostaining was present at mild, moderate and strong intensities that variedin differenttumor cells. Furthermore, the density and quantity of IL-12R $\beta 2^{+}$and IL-23R+TILsvaried depending on the area (intra-tumor or peripheral-tumor), peripheral necrosis and infective inflammation, while the ratios of IL-12R $\beta 2^{+}$and IL-23R+TILs remained relatively steady. In LC, WD tumors consistently

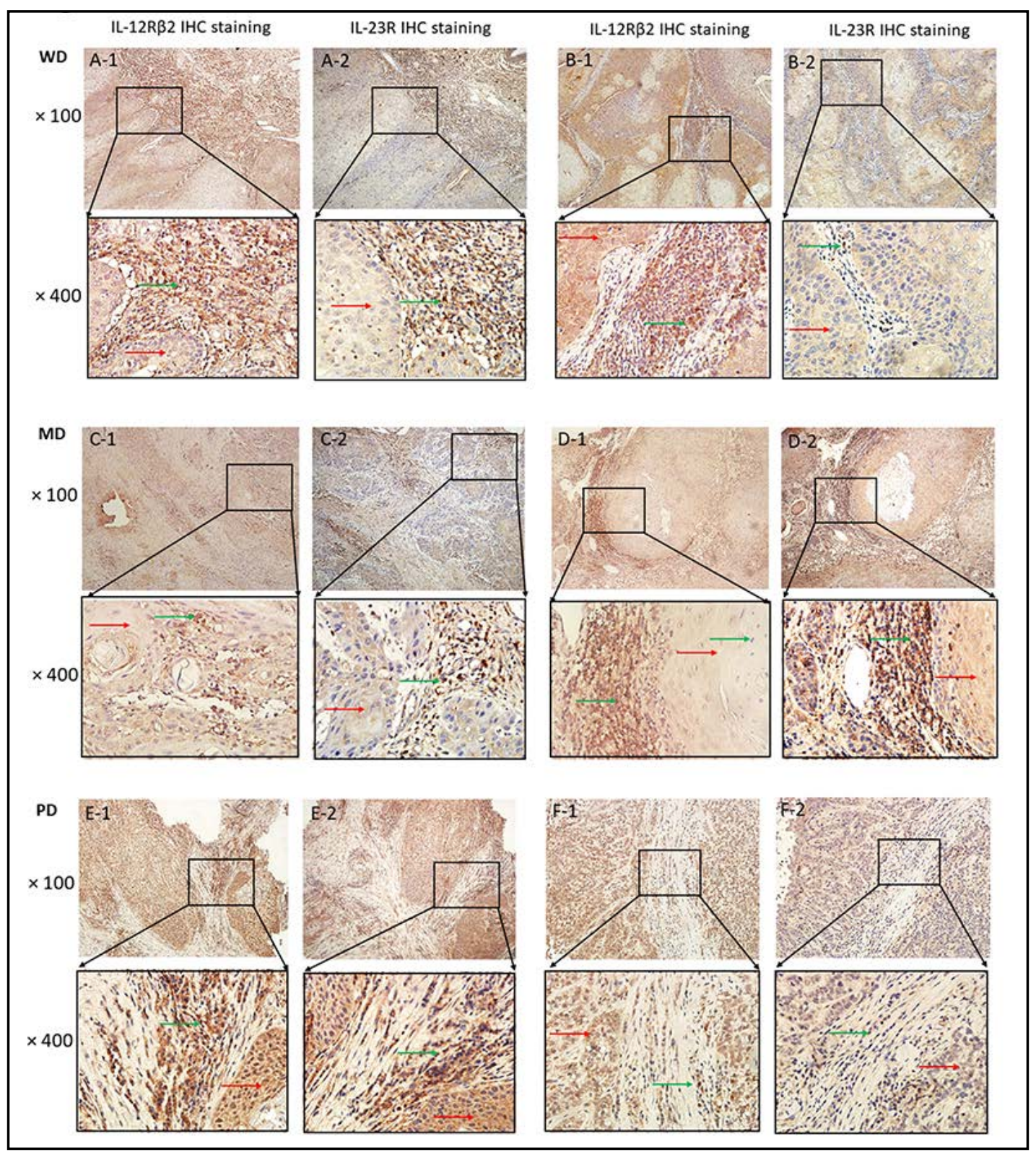

Fig. 2. IL-12Rß2 and IL-23R immunostaining in LC cancer tissues. (A) and (B), (C) and (D), and (E) and (F) are well-differentiated (WD), moderately differentiated (MD) and poorly differentiated (PD) tumor samples, respectively, from two patients. Furthermore, IL-12R $\beta 2$ - and IL-23R-immunostaining in consecutively stained sections from the same tumor specimen are marked with $(-1)$ and (-2), respectively. Red arrow indicated tumor cells (either IL-12R $\beta 2^{ \pm}$or IL-23R $\mathrm{R}^{ \pm}$) while green arrow indicated TILs (either IL-12R $\beta 2^{ \pm}$or IL-23R $\mathrm{R}^{ \pm}$. 
Table 4. Demographics and risk factors with IL-12Rß2/IL-23R expression or positive TIL ratio in 61 LC patients

\begin{tabular}{|c|c|c|c|c|c|c|c|c|c|c|c|c|c|}
\hline \multirow[b]{2}{*}{$\begin{array}{l}\text { Clinicopathologic } \\
\text { characteristic }\end{array}$} & \multirow[b]{2}{*}{$\begin{array}{l}\text { Total } \\
\mathrm{N}(\%)\end{array}$} & \multicolumn{3}{|c|}{ IL-12R $\beta 2$ expression } & \multicolumn{3}{|c|}{ IL-23R expression } & \multicolumn{3}{|c|}{ IL-12R $\beta 2+$ TIL ratio } & \multicolumn{2}{|c|}{ IL-23R+ TIL ratio } & \multirow[b]{2}{*}{$P$} \\
\hline & & High & Low & $\mathrm{P}$ & High & Low & $\mathrm{P}$ & $\begin{array}{l}\text { High- } \\
\text { ratio }\end{array}$ & $\begin{array}{l}\text { Low- } \\
\text { ratio }\end{array}$ & $P$ & $\begin{array}{l}\text { High- } \\
\text { ratio }\end{array}$ & $\begin{array}{l}\text { Low- } \\
\text { ratio }\end{array}$ & \\
\hline Age, years & & & & 0.423 & & & 0.684 & & & 0.765 & & & 0.249 \\
\hline$\geq 60$ & $37(60.7)$ & $22(36.1)$ & $15(24.6)$ & & $12(19.7)$ & $25(41.0)$ & & $14(23.0)$ & $23(37.7)$ & & $24(39.3)$ & $13(21.3)$ & \\
\hline$<60$ & $24(39.3)$ & $17(27.9)$ & $7(11.4)$ & & $9(14.7)$ & $15(24.6)$ & & $10(16.4)$ & $14(23.0)$ & & $12(19.7)$ & $12(19.7)$ & \\
\hline Sex & & & & 0.179 & & & 0.164 & & & 0.417 & & & 0.226 \\
\hline Female & $1(1.6)$ & 0 & $1(1.6)$ & & $1(1.6)$ & 0 & & 0 & $1(1.6)$ & & 0 & $1(1.6)$ & \\
\hline Male & $60(98.4)$ & $39(63.9)$ & $21(34.5)$ & & $20(32.8)$ & $40(65.6)$ & & $24(39.3)$ & $36(59.1)$ & & $36(59.1)$ & $24(39.3)$ & \\
\hline Smoking & & & & 0.777 & & & 0.257 & & & 0.963 & & & 0.140 \\
\hline Ever & $51(83.6)$ & $33(54.1)$ & $18(29.5)$ & & $16(26.2)$ & $35(57.4)$ & & $20(32.8)$ & $31(51.8)$ & & $28(45.9)$ & $23(37.7)$ & \\
\hline Never & $10(16.4)$ & $6(9.8)$ & $\begin{array}{l}4(6.6) \\
-1\end{array}$ & & $5(8.2)$ & $5(8.2)$ & & $4(6.6)$ & $\begin{array}{l}6(9.8) \\
6(1)\end{array}$ & & $8(13.1)$ & $2(3.3)$ & \\
\hline Alcohol & & & & 0.366 & & & 0.059 & & & 0.856 & & & 0.985 \\
\hline Ever & $44(72.1)$ & $28(45.9)$ & $16(26.2)$ & & $12(19.7)$ & $32(42.5)$ & & $17(27.9)$ & $27(44.3)$ & & $26(42.3)$ & $18(29.5)$ & \\
\hline Never & $17(27.9)$ & $11(18.1)$ & $\begin{array}{l}6(9.8) \\
-198\end{array}$ & & $9(14.7)$ & $8(13.1)$ & & $10(16.4)$ & $7(11.5)$ & & $10(16.4)$ & $7(11.5)$ & \\
\hline Primary tumor site & & & & 0.491 & & & 0.444 & & & 0.382 & & & 0.219 \\
\hline Glottis & $32(52.5)$ & $21(34.4)$ & $11(18.0)$ & & $13(21.3)$ & $19(31.0)$ & & $15(24.6)$ & $17(27.9)$ & & $20(32.8)$ & $12(19.7)$ & \\
\hline Superior glottis & $27(44.3)$ & $16(26.2)$ & $11(18.0)$ & & $7(11.5)$ & $20(32.8)$ & & $8(13.1)$ & 19(31.1) & & $16(26.2)$ & $11(18.0)$ & \\
\hline Inferior glottis & $2(3.3)$ & $2(3.3)$ & 0 & & $1(1.6)$ & $1(1.6)$ & & $1(1.6)$ & $1(1.6)$ & & 0 & $2(3.3)$ & \\
\hline Differentiation & & & & 0.923 & & & 0.210 & & & 0.530 & & & 0.500 \\
\hline Well & $30(49.2)$ & $19(31.1)$ & $11(18.0)$ & & $8(13.1)$ & $22(36.1)$ & & $13(21.3)$ & $17(27.9)$ & & $19(31.1)$ & $11(18.0)$ & \\
\hline Moderate/poor & $31(51.8)$ & $20(32.8)$ & $11(18.0)$ & & $13(21.3)$ & $18(29.5)$ & & $11(18.0)$ & $20(32.8)$ & & $17(27.9)$ & $14(23.0)$ & \\
\hline TNM stage & & & & 0.932 & & & 0.753 & & & 0.767 & & & 0.905 \\
\hline I or II & $42(68.9)$ & $27(44.3)$ & $15(24.6)$ & & $15(24.6)$ & $27(44.3)$ & & $16(26.2)$ & $26(42.6)$ & & $25(41.0)$ & $17(27.9)$ & \\
\hline III or IV & $19(31.1)$ & $12(19.7)$ & $7(11.4)$ & & $\begin{array}{l}6(9.8) \\
\end{array}$ & $13(21.3)$ & & $\begin{array}{l}8(13.2) \\
\end{array}$ & $11(18.0)$ & & $11(18.0)$ & $8(13.1)$ & \\
\hline
\end{tabular}

manifested moderate and strongIL-12R $\beta 2$-immunostaining intensity on tumor cells, with a large quantity of IL-12R $\beta 2^{+}$TILs in the intratumoral and peritumoral areas. WD tumor cells exhibited mild and moderate IL-23R-immunostaining intensity, with fewer (compared with IL-12R $\beta 2^{+}$) IL-23R $\mathrm{R}^{+}$TILs on the most adjacent embedded pathology section. Furthermore, tumors that were moderately differentiated (MD) consistently had reduced IL-12R $\beta 2$ immunostainingintensity and decreased levels of IL-12R $\beta 2^{+}$TILs, but increased IL-23R immunostaining intensity and increased levels of IL-23R ${ }^{+}$TILs. Moreover, poorly differentiated (PD) tumors had variable (mild, moderate and strong) intensities of IL-12R $\beta 2$ and IL-23R-immunostaining, with dynamic, changing quantities and ratios of IL-12R $\beta 2^{+}$and IL-23R ${ }^{+}$TILs (Fig. 2).

Taken together, we found that tumor cell differentiation potentially correlated with the (tumor cell) expression of IL-12R $\beta 2$ and IL-23R and the ratios of IL-12R $\beta 2^{+}$and IL-23R+TILs. Therefore, we further compared and analyzed the correlation between IL-12R $\beta 2$ and IL-23R tumor cell expression and the ratios of positive TILs. Demographic characteristics by group are presented in Table 4.

Expression differences of IL-12Rß2 and IL-23R in tumors and their correlations with tumor cell differentiation

Overall, among the 61 cancer tissues, we found that IL-12R 32 expression was higher than that of IL-23R (Fig. 3A-1). Furthermore, when stratified by tumor cell differentiation (WD and MPD), we found that the expression difference was more predominant in WD cancer tissues (Fig. 3A-2), whereas no significant difference was found in the MPD cancer tissues (Fig. 3A-3). Likewise, linear regression analysis found that IL-12R $\beta 2$ expression correlated with IL-23R expression in the overall sample of 61 cancer tissues (Fig. 3B-1). Moreover, when stratified by tumor cell differentiation (WD and MPD), we found that linear regression significance was more prominent in WD cancer tissues (Fig. 3B-2), whereas there was no significant difference in MPD cancer tissues (Fig. 3B-3). Taken together, opposing roles of IL-12R $\beta 2$ and IL-23R expression had expressive correlation, which created an equilibrium within the tumor cells. Furthermore, WD tumors achieved that equilibrium and were associated with favorable prognosis, while MPD tumors did not achieve that equilibrium and were associated with unfavorable prognosis. 

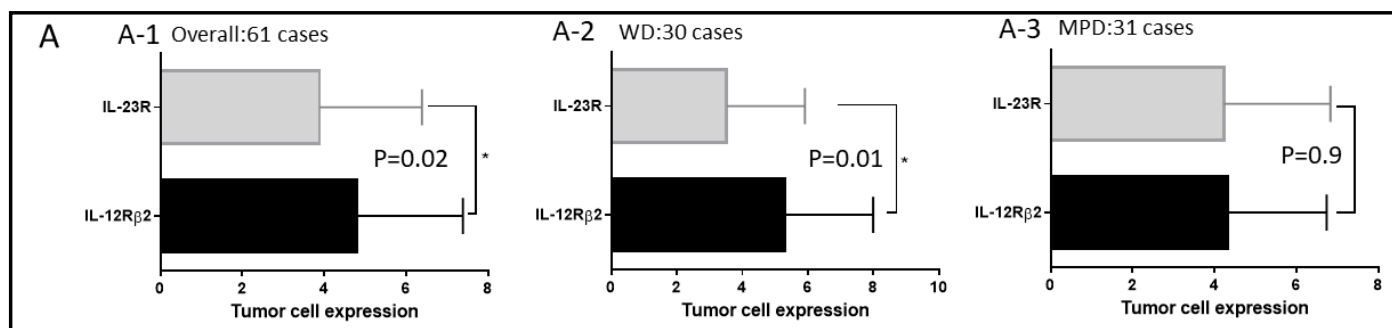

B B-1 Overall:61 cases
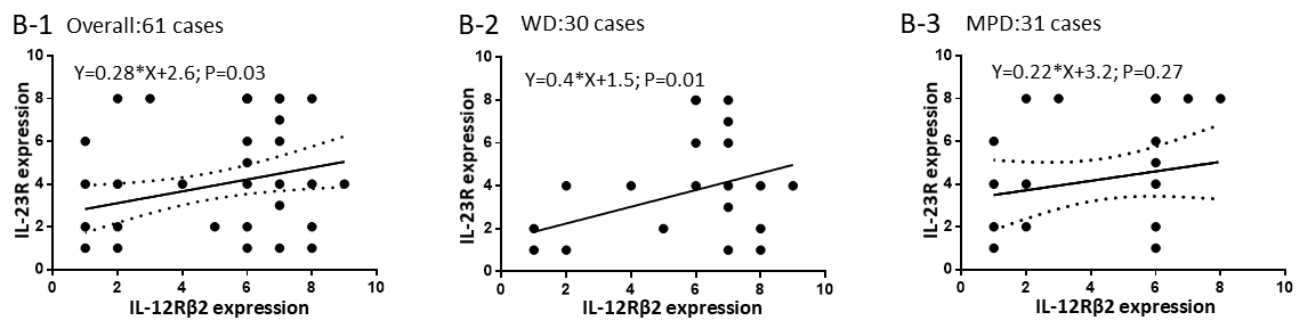

Fig. 3. Paired Student t-test comparison (A) and linear correlation (B) between IL-12R $\beta 2$ - and IL-23Rimmunostaining on tumor cell expression. (A-1) and (B-1), the 61 total cases; (A-2) and (B-2), the 30 welldifferentiated (WD) cases; (A-3) and (B-3), the 31 moderate and poorly differentiated (MPD) cases. ${ }^{*}, \mathrm{P}<0.05$.

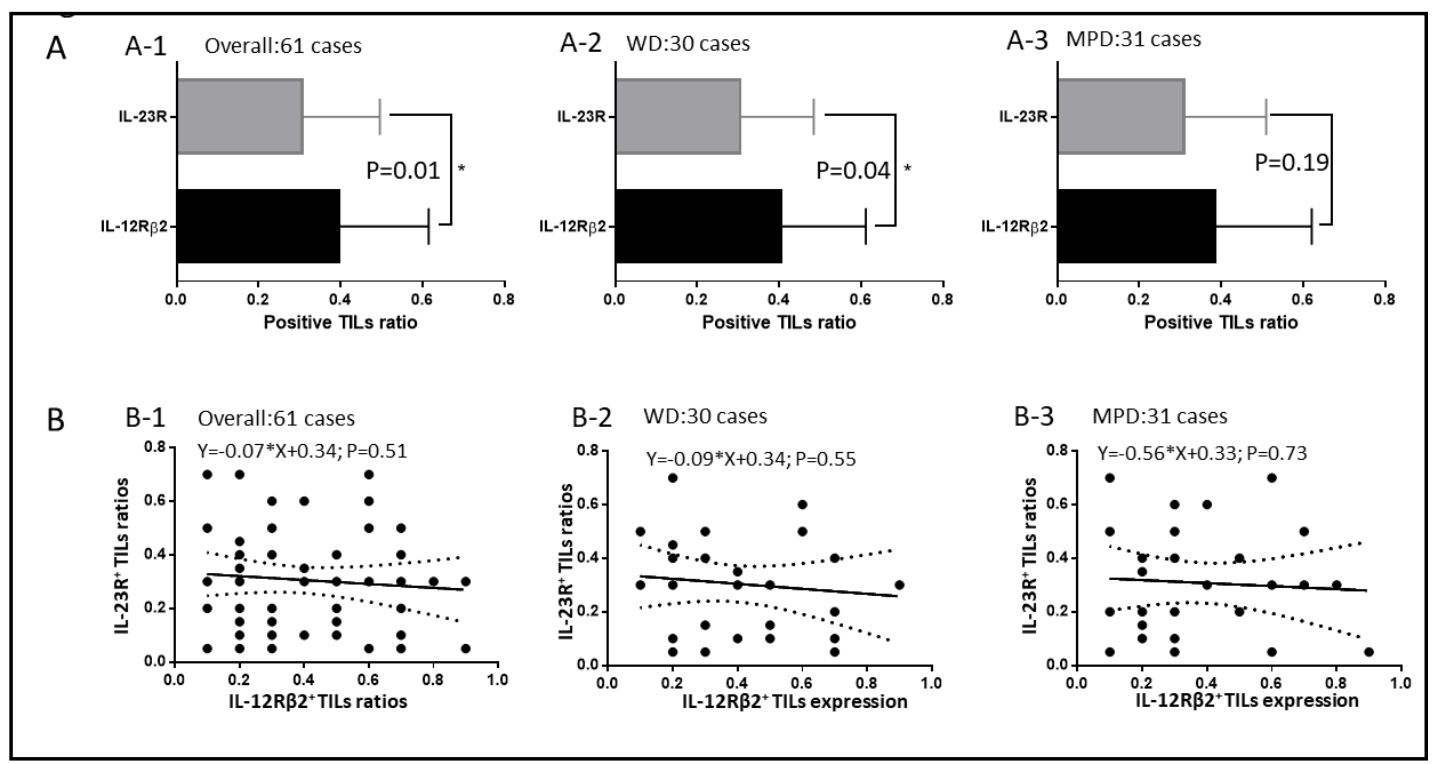

Fig. 4. Paired Student t-test comparison (A) and linear correlation (B) between $\mathrm{IL}-12 \mathrm{R} \beta 2^{+}$and $\mathrm{IL}^{-}$ $23 \mathrm{R}^{+}$immunostaining TIL ratios. (A-1) and (B-1), the 61 total cases; (A-2) and (B-2), the 30 well-differentiated (WD) cases; (A-3) and (B-3), the 31 moderate and poorly differentiated (MPD) cases. * $\mathrm{P}<0.05$.

\section{$I L-12 R \beta 2^{+}$and IL-23R+ TIL ratio differences in tumors and correlations with tumor cell differentiation}

In the total sample of 61 cancer tissues, we found that IL-12R $\beta 2^{+}$TIL ratios were higher than the IL-23R $\mathrm{R}^{+}$TIL ratios (Fig. 4A-1). Furthermore, when stratified by tumor cell differentiation (WD and MPD), we found that the significance of the difference in ratios of IL$12 \mathrm{R} \beta 2^{+}$and IL-23R $\mathrm{R}^{+}$TILs was more prominent in WD cancer tissues (Fig. 4A-2), whereas no significant difference was found in MPD cancer tissues (Fig. 4A-3). However, no significant linear correlation was found between the ratios of IL-12R $\beta 2^{+}$and IL-23R ${ }^{+}$TILs (Fig. 4B-1; 4B-2; 4B-3). 


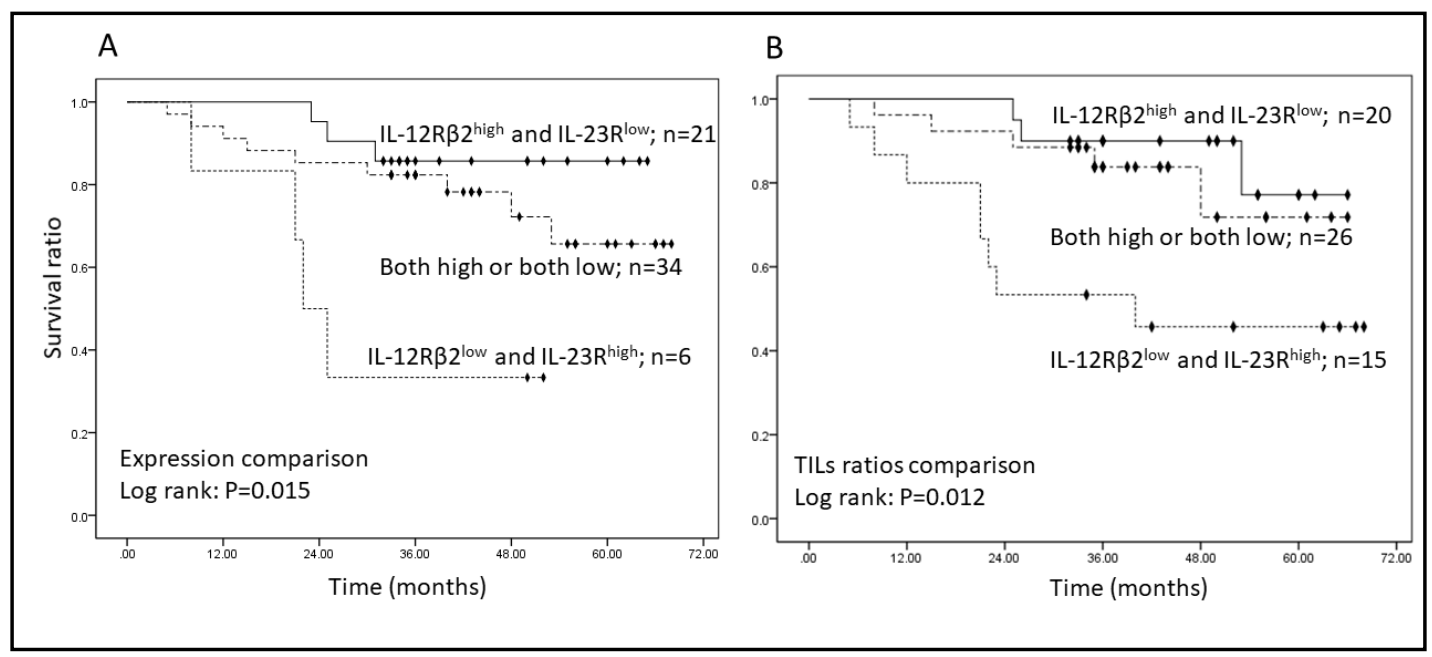

Fig. 5. Survival analysis among 61 patients. (A) Patients with tumor cell IL-12R $\beta 2^{\text {high }}$ and IL-23R ${ }^{\text {low }}$ expression $(n=21)$ had a higher survival rate than patients with IL-12R $\beta 2^{\text {low }}$ and IL-23R $R^{\text {high }}(n=6)$ and patients with IL$12 \mathrm{R} \beta 2$ and IL-23Rexpression that was both low and both high $(\mathrm{n}=34)$. (B) Patients with IL-12R $\beta 2^{\text {high }}$ and IL-23R $^{\text {low }}$ TILs ratios $(n=20)$ had a higher survival rate than patients with IL-12R $\beta 2^{\text {low }}$ and IL-23R ${ }^{\text {high }}$ TIL ratios $(n=15)$ and patients with IL-12R $\beta 2$ and IL-23RTIL ratios that were both low and both high $(n=26)$.

Kaplan-Meier analysis of combined expression of $I L-12 R \beta 2$ and $I L-23 R$ on survival

Kaplan-Meier analysis revealed that patients with tumor cell IL-12R $\beta 2^{\text {high }}$ and IL-23R ${ }^{\text {low }}$ expression had a higher survival rate than patients with IL-12R $\beta 2^{\text {low }}$ and IL-23R ${ }^{\text {high }}$ and those with both high or both low IL12R $\beta 2$ and IL-23Rexpression (log rank, $\mathrm{p}=0.015$; Fig. 5A). Likewise, patients with positive IL-12R $\beta 2^{\text {high }}$ and IL-23R $^{\text {low }}$ TIL ratios had a higher survival rate than patients with positive ratios of IL-12R $\beta 2^{\text {low }}$ and IL-23R ${ }^{\text {high }}$ TILs or of both low and both highIL-12R $\beta 2$ and IL-23RTILs (log rank, p=0.012; Fig. 5B).
Table 5. OS analysis on IL-12R $\beta 2 / \mathrm{IL}-23 \mathrm{R}$ tumor expression in LC patients $(\mathrm{N}=61)$

\begin{tabular}{|c|c|c|c|c|c|}
\hline $\begin{array}{l}\text { IL-12R } \beta 2 / \text { IL-23R } \\
\text { expression }\end{array}$ & $\mathrm{N}$ & $\begin{array}{r}\mathrm{cHR} \\
\mathrm{HR}(95 \% \mathrm{CI}) \\
\end{array}$ & $\mathrm{P}$ & $\begin{array}{r}\text { aHR } \\
\text { HR (95\% CI) } \\
\end{array}$ & $\mathrm{P}$ \\
\hline \multicolumn{6}{|l|}{ IL-12R $\beta 2$ expression } \\
\hline Low (Ref.) & 22 & 1.0 & & 1.0 & \\
\hline High & 39 & $0.3(0.1-0.9)$ & 0.029 & $0.3(0.1-0.8)$ & 0.018 \\
\hline \multicolumn{6}{|l|}{ IL-23R expression } \\
\hline High (Ref.) & 21 & 1.0 & & 1.0 & \\
\hline Low & 40 & $0.4(0.1-1.0)$ & 0.053 & $0.3(0.1-0.9)$ & 0.028 \\
\hline \multicolumn{6}{|l|}{ Joint expression } \\
\hline IL-12R $\beta 2^{\text {low }}$ and IL-23high (Ref.) & 6 & 1.0 & & 1.0 & \\
\hline Both low or high & 34 & $0.5(0.1-2.0)$ & 0.332 & $0.4(0.1-1.7)$ & 0.211 \\
\hline IL-12R $\beta 2^{\text {high }}$ and IL-23R low & 21 & $0.1(0.0-0.6)$ & 0.011 & $0.1(0.0-0.8)$ & 0.032 \\
\hline
\end{tabular}

Table 6. OS analysis on IL-12R $\beta 2 / \mathrm{IL}-23 \mathrm{R}$ TIL ratio in LC patients $(\mathrm{N}=61)$

\begin{tabular}{|c|c|c|c|c|c|}
\hline $\begin{array}{l}\text { IL-12R } \beta 2 / \mathrm{IL}-23 \mathrm{R} \\
\text { ratio }\end{array}$ & $\mathrm{N}$ & $\begin{array}{r}\text { cHR } \\
\text { HR }(95 \% \mathrm{CI}) \\
\end{array}$ & $\mathrm{P}$ & $\begin{array}{r}\text { aHR } \\
\text { HR (95\% CI) }\end{array}$ & $\mathrm{P}$ \\
\hline \multicolumn{6}{|l|}{ IL-12R $\beta 2$ ratio } \\
\hline Low (Ref.) & 37 & 1.0 & & 1.0 & \\
\hline High & 24 & $0.3(0.1-1.0)$ & 0.056 & $0.1(0.0-0.8)$ & 0.013 \\
\hline \multicolumn{6}{|l|}{ IL-23R ratio } \\
\hline High (Ref.) & 36 & 1.0 & & 1.0 & \\
\hline Low & 25 & $1.0(0.4-2.5)$ & 0.986 & $0.7(0.2-2.5)$ & 0.530 \\
\hline \multicolumn{6}{|l|}{ Joint ratio } \\
\hline IL-12R $\beta 2^{\text {low }}$ and IL-23R ${ }^{\text {high }}$ (Ref.) & 15 & 1.0 & & 1.0 & \\
\hline Both low or high & 26 & $0.7(0.2-2.5)$ & 0.594 & $0.9(0.2-5.0)$ & 0.865 \\
\hline IL-12R $\beta 2^{\text {high }}$ and IL-23R low & 20 & $0.2(0.1-0.8)$ & 0.018 & $0.1(0.0-0.4)$ & 0.001 \\
\hline
\end{tabular}

Multivariable analysis of combined expression of IL-12RR2 and IL-23R on prognosis

Multivariable analysis indicated a significant association between joint tumor cell expression (IL-12R $\beta 2^{\text {low }}$ and IL-23R $\mathrm{R}^{\text {high }}$ ) and overall survival (hazard ratio, $0.1 ; 95 \%$ confidence interval, 0.0-0.8, Table 5). Likewise, a significant association between joint TIL ratio (IL-12R $\beta 2^{\text {low }}$ and IL-23R $\mathrm{R}^{\text {high }}$ ) and overall survival (hazard ratio, 0.1; 95\% confidence interval, 0.0-0.4) was also identified (Table 6). 


\section{Cellular Physiology Cell Physiol Biochem 2018;50:1041-1054

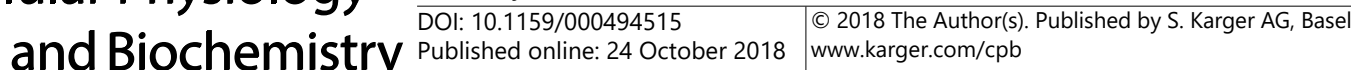

Tao et al.: Opposing Roles of IL-12Rß2 and IL-23R in Laryngeal Cancer

\section{Discussion}

In the LC tumor microenvironment, IL-12R $\beta 2$ and IL-23R are two closely related receptors that participate via critical but opposing roles in tumor immunity [13-15]. In this study with 61 LC cases, we evaluated their combined roles by assessing tumor cell expression and calculating TIL positivity ratios. We found that LC tumor cells had higher IL-12R $\beta 2$ expression than IL-23R expression. A significant correlation between IL-12R $\beta 2$ and IL-23R expression was identified overall in the LC tissues, particularly among welldifferentiated LCs. Furthermore, patients with high tumor cell IL-12R $\beta 2$ expression and low IL-23R expression had a higher survival rate than patients with low IL-12R $\beta 2$ and high IL23Rexpression or high or low expression of both IL-12R $\beta 2$ and IL-23R. Similar comparison did for IL-12R $\beta 2^{+}$TIL ratio and IL-23R+ TIL ratio in LC tissues. In addition, similar correlations between IL-12R $\beta 2$ and IL-23R positive ratios were identified, which were significant in welldifferentiated LC. Moreover, patients with positive ratios of IL-12R $\beta 2^{\text {high }}$ and IL-23R ${ }^{\text {low }}$ TILs had a higher survival rate than patients with positive ratios of IL-12R $\beta 2^{\text {low }}$ and IL-23R ${ }^{\text {high }}$ TILs or positive ratios of either IL-12R $\beta 2^{\text {low }}$ and IL-23R ${ }^{\text {low }}$ or IL-12R $\beta 2^{\text {high }}$ and IL-23R ${ }^{\text {high }}$ TILs.

A favorable prognosis was associated with WD LC in which cancer cells were immunolabeled with high IL-12R $\beta 2$ and low IL-23R expression. A cancer cell differentiation (histological grade) value for prognosis has been identified in breast cancer; however, a similar value in LC has not been fully clarified due to the following three factors: the confounded etiology; the variable TNM staging; and the limited morphological criteria [40]. In our study, we separated 61 patients into groups with WD or MPD tumors. According to the classification criteria, the WD tissues possessed well-defined borders, single mitoses, few enlarged nuclei and a high level of keratin [40]. These WD cancer cells were also characterized by high IL-12R $\beta 2$ and low IL-23R expression. While the IL-23/IL-23R axis transcriptionally activates the STAT3 gene, which can further promote tumor cell proliferation $[13,19]$, the IL-12/IL-12R $\beta 2$ axis mediates STAT4 activation in opposing regulation of the tumor cells [41]. In vivo, IL-12R $\beta 2^{+}$B16 melanoma clones showed significantly inhibited tumorigenicity compared with IL-12R $\beta 2^{-}$clones in IL-12R $\beta 2$-KO mice, while IL-23R-KO mice also demonstrated inhibited tumorigenicity for both B16F10 melanoma and LL2 lung carcinoma [13]. These results indicate that intrinsic equilibrium between IL-12R $\beta 2$ and IL23R and the mechanisms for maintaining that equilibrium are associated with tumor cell differentiation and tumor invasion. Here, we observed a significant correlation between IL$12 \mathrm{R} \beta 2$ and IL-23R expression in WD cancer cells, whereas a similar significant correlation was not observed in MPD tumors. This result may indicate that IL-12R $\beta 2$ and IL-23R have opposing roles in tumor progression and thereby create an immune-mediated equilibrium in WD cancer cells, whereas MPD tumors had lost that equilibrium, leading to aggressive invasiveness and an unfavorable prognosis.

TILs exert both host-protecting and tumor-sculpting effects on tumorigenesis, and the opposing roles of IL-12R $\beta 2^{+}$and IL-23R $\mathrm{R}^{+}$TILs create a homeostasis (balanced equilibrium) that is associated with good prognosis. Expression of both IL-12R $\beta 2$ and IL-23R are highly regulated on $\mathrm{T}$ cells as contributors to a Th cell phenotype commitment [17]. Specifically, IFN- $\gamma$ antagonizes TGF $\beta$ and IL- 6 in naïve CD4+ T cell plasticity as follows: IFN- $\gamma$ stimulates transcription factor T-bet expression, and upregulated T-bet in turn can promote IL-12R $\beta 2$ expression and thereby maintain the Th1 cell phenotype to perform the host-protecting role via STAT4-IFN- $\gamma$ activation. In contrast, TGF $\beta$ and IL- 6 promote Th17 cell differentiation via IL-23R upregulation and STAT3 activation and differentiated CD4+ Th17 cells in turn can secrete IL-17 to further enhance the tumor-sculpting role $[13,14,17]$. Therefore, opposing roles of IL-12R $\beta 2^{+}$and IL-23R $\mathrm{R}^{+}$TILs create a homeostasis (balanced equilibrium). In our studies, we found that in WD cancer cells, a high ratio of IL- $12 \mathrm{R} \beta 2^{+}$and low ratio of IL$23 \mathrm{R}^{+}$TILs was associated with a favorable prognosis. However, MPD cancer cells had lost that homeostasis and thus exhibited an unfavorable prognosis. This result suggests that homeostasis is associated with a favorable prognosis in LC cancer. 


\section{Cellular Physiology Cell Physiol Biochem 2018;50:1041-1054

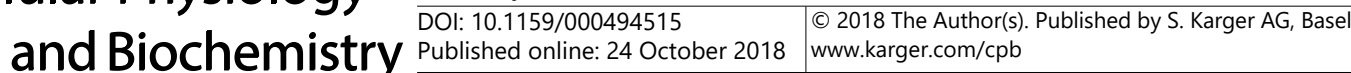 \\ Tao et al.: Opposing Roles of IL-12Rß2 and IL-23R in Laryngeal Cancer}

In the tumor microenvironment, low oxygen tension (hypoxia) may disrupt the homeostasis of IL-12R 32 and IL-23R in cancer cells and in TILs via blocking tumor cell differentiation or the TIL lineage. Solid tumors constantly manifest hypoxia, and hypoxic tumors appear to be PD [42]. In addition, the cause of the poor differentiation is that the hypoxia niche can maintain undifferentiated states of CSCs and TIL naïve phenotypes via enhanced EMT for cancer stem cells or blocked commitment for the IL-12R $\beta 2^{+}$TIL lineage $[43,44]$. PD cancer cells exhibit accelerated tumor growth and consume more oxygen; this increased oxygen consumption devastates the tumor hypoxic microenvironment and thereby causes necrosis at the tumor center [43]. In our study, we found that PD tumors were consistently accompanied by necrosis, where the viable tumor cells had low IL-12R $\beta 2$ expression and very low ratios of IL-12R $\beta 2^{+}$TILs (Fig. 4). Therefore, this phenomenon indicates that hypoxia is associated with low IL-12R $\beta 2$ expression within both tumor cells and TILs; however, the intrinsic mechanism by which hypoxia downregulates IL-12R $\beta 2$ expression remains largely unknown and requires further research.

In previous studies, the opposing roles of IL-12R $\beta 2$ and IL-23R were shown to be regulated by epigenetic modifications in which silencing $I L-12 R \beta 2$ and/or activating $I L-23 R$ served as potential mechanisms for cancer cell immunoediting [6, 7] and TIL plasticity [45]. $I L-12 R \beta 2$ and $I L-23 R$ epigenetic modifications mainly included $C p G$ island methylation and histone post-translation modification [45-49]. In human lung cancer cells, $I L-23 R$ was shown to be upregulated via the TGF $\beta 1$ signaling pathway, while aberrant methylation could silence $I L-12 R \beta 2$ and $I L-12 R \beta 2$, which serve as a potential prognostic factor for lung adenocarcinoma [32]. Furthermore, in pediatric B-acute lymphoblastic leukemia cells, exon 1 methylation of $I L-12 R \beta 2$ gene can also silence $I L-12 R \beta 2$, which is a cancer cell immunoediting mechanism [49]. Moreover, for CD4+ Th1/Th17 TIL plasticity, T-bet activation was crucial and essential, and T-bet was regulated by histone post-translational modification [45, 46]. H3K4me3 was associated with T-bet activation, while H3K27me3 was associated with T-bet silencing. When the same regions were modified by both H3K4me3 and H3K27me3, the co-localized DNA modification region was called the 'bivalent' domain. The T-bet region, as one vital bivalent domain, can be activated by removal of the H3K27me3 suppressive effect and can thereby promote Th1 cell plasticity through elevated IL-12R $\beta 2$ expression. In contrast, upregulated IL-23R expression is associated with Th17 cell plasticity with maintenance of the H3K27me3 effect by TGF- $\beta 1[45,47]$. However, the precise role of IL-23 on Th17 cell plasticity remains unclear and requires further research within the tumor microenvironment.

Many in vivo and in vitro studies have identified the opposing roles of IL-12Rß2 and IL-23R within the tumor microenvironment on tumor cells and TILs; furthermore, hypoxia and tumorigenesis may genetically and epigenetically regulate tumor cell differentiation and TIL plasticity, which may further impact immunoediting CSCs and promote tumor evasion and metastasis $[45,49]$. However, the intrinsic mechanisms through which genetic and epigenetic modification affect the homeostasis of IL-12R $\beta 2$ and IL-23R and their impact on tumor cell immunoediting remain largely unknown due to methodological limitation [32]. Furthermore, many studies have focused on specific positive ratios of lymphocyte subtypes and their hazard ratios for prognosis, but there was high variability in the density and quantity of intra-tumor or peripheral-tumor TILs with dynamic alterations within the hypoxic niches (including necrosis) [34]. This variety causes difficulty in IL-12R $\beta 2^{+}$and IL$23 \mathrm{R}^{+} \mathrm{TIL}$ calculations. Furthermore, semi-quantitative analysis of tumor cell expression of IL-12R $\beta 2$ and IL-23R via IHC method cannot precisely evaluate the dynamic shifting phases of elimination, equilibrium and escape during tumor immunoediting [5, 7]. In addition, our limited sample size may cause a possible selection bias that could confound the results of this study; thus, further well-designed larger studies are required to validate our findings. 


\section{Cellular Physiology Cell Physiol Biochem 2018;50:1041-1054 \begin{tabular}{ll|l} 
and Biochemistry Published online: 24 October 2018 & $\begin{array}{l}\text { (c) } 2018 \text { The Author(s). Published by S. Karger AG, Basel } \\
\text { www.karger.com/cpb }\end{array}$ \\
\hline
\end{tabular}}

\section{Conclusion}

Taken together, our results suggest that IL-12R $\beta 2$ and IL-23R create a homeostasis in the tumor cells and TILs, and this homeostasis associated with good prognosis. High IL-12R $\beta 2$ expression and low IL-23R expression were associated with WD tumors and less hypoxia within the tumor microenvironment, and thereby indicated a favorable prognosis. Likewise, tumors associated with positive ratios of high IL-12R $\beta 2$ and low IL-23R TILs were also associated with a higher degree of differentiation and less hypoxia and indicated a favorable prognosis. However, the intrinsic mechanisms of epigenetic immunoediting for IL-12R $\beta 2$ and IL-23R remain largely unknown. To confirm our findings and elucidate the underlying mechanisms, additional larger population or functional studies are warranted for validation.

\section{Abbreviations}

IL (interleukin); IL-23R (interleukin-23 receptor); IRS (immunoreactive score); LC (laryngeal cancer); WD (well-differentiated); PD (poorly differentiated); MPD (moderately and poorly differentiated); STAT (signal transducer and activator of transcription); TGF (transforming growth factor); Th (T helper); TIL (tumor-infiltrating lymphocyte); IHC (immunohistochemistry); EMT (epithelial-mesenchymal transition,); CSC (cancer stem cells); MCA (methylcholanthrene); HR (hazard ratio.).

\section{Acknowledgements}

This work was supported by China National Science Foundation (Grant No. 81670946, Grant No. 81641104).

\section{Disclosure Statement}

The authors have no conflicts of interest to declare.

\section{References}

1 Forastiere AA, Goepfert H, Maor M, Pajak TF, Weber R, Morrison W, Glisson B, Trotti A, Ridge JA, Chao C, Peters G, Lee DJ, Leaf A, Ensley J, Cooper J: Concurrent chemotherapy and radiotherapy for organ preservation in advanced laryngeal cancer. N Engl J Med 2003;349:2091-2098.

-2 Chen W, Zheng R, Baade PD, Zhang S, Zeng H, Bray F, Jemal A, Yu XQ He J: Cancer statistics in China, 2015. CA Cancer J Clin 2016;66:115-132.

-3 Mao L, Hong WK, Papadimitrakopoulou VA: Focus on head and neck cancer. Cancer Cell 2004;5:311-316.

-4 Chaffer CL, Weinberg RA: A perspective on cancer cell metastasis. Science 2011;331:1559-1564.

5 Dunn GP, Bruce AT, Ikeda H, Old LJ, Schreiber RD: Cancer immunoediting: from immunosurveillance to tumor escape. Nat Immunol 2002;3:991-998.

6 Mittal D, Gubin MM, Schreiber RD, Smyth MJ: New insights into cancer immunoediting and its three component phases--elimination, equilibrium and escape. Curr Opin Immunol 2014;27:16-25.

7 Schreiber RD, Old LJ, Smyth MJ: Cancer immunoediting: integrating immunity's roles in cancer suppression and promotion. Science 2011;331:1565-1570.

-8 Quezada SA, Peggs KS, Simpson TR, Allison JP: Shifting the equilibrium in cancer immunoediting: from tumor tolerance to eradication. Immunol Rev 2011;241:104-118.

-9 de Wit J, Souwer Y, van Beelen AJ, de Groot R, Muller FJ, Klaasse Bos H, Jorritsma T, Kapsenberg ML, de Jong EC, van Ham SM: CD5 costimulation induces stable Th17 development by promoting IL-23R expression and sustained STAT3 activation. Blood 2011;118:6107-6114. 


\section{Cellular Physiology Cell Physiol Biochem 2018;50:1041-1054 \begin{tabular}{l|l|l} 
and Biochemistry Published onlline: 24 October 2018 & $\begin{array}{l}\text { (c) } 2018 \text { The Author(s). Published by S. Karger AG, Basel } \\
\text { www.karger.com/cpb }\end{array}$
\end{tabular}}

-10 Tosolini M, Kirilovsky A, Mlecnik B, Fredriksen T, Mauger S, Bindea G, Berger A, Bruneval P, Fridman WH, Pages F, Galon J: Clinical impact of different classes of infiltrating T cytotoxic and helper cells (Th1, th2, treg, th17) in patients with colorectal cancer. Cancer Res 2011;71:1263-1271.

11 Hatton RD: TGF-beta in Th17 cell development: the truth is out there. Immunity 2011;34:288-290.

12 Teng MW, Vesely MD, Duret H, McLaughlin N, Towne JE, Schreiber RD, Smyth MJ: Opposing roles for IL-23 and IL-12 in maintaining occult cancer in an equilibrium state. Cancer Res 2012;72:3987-3996.

13 Kortylewski M, Xin H, Kujawski M, Lee H, Liu Y, Harris T, Drake C, Pardoll D, Yu H: Regulation of the IL-23 and IL-12 balance by Stat3 signaling in the tumor microenvironment. Cancer Cell 2009;15:114-123.

14 Watford WT, Hissong BD, Bream JH, Kanno Y, Muul L, O’Shea JJ: Signaling by IL-12 and IL-23 and the immunoregulatory roles of STAT4. Immunol Rev 2004;202:139-156.

-15 Hoeve MA, Savage ND, de Boer T, Langenberg DM, de Waal Malefyt R, Ottenhoff TH, Verreck FA: Divergent effects of IL-12 and IL-23 on the production of IL-17 by human T cells. Eur J Immunol 2006;36:661-670.

16 McGovern D, Powrie F: The IL23 axis plays a key role in the pathogenesis of IBD. Gut 2007;56:1333-1336.

17 Teng MW, Bowman EP, McElwee JJ, Smyth MJ, Casanova JL, Cooper AM, Cua DJ: IL-12 and IL-23 cytokines: from discovery to targeted therapies for immune-mediated inflammatory diseases. Nat Med 2015;21:719729.

18 Sato E, Olson SH, Ahn J, Bundy B, Nishikawa H, Qian F, Jungbluth AA, Frosina D, Gnjatic S, Ambrosone C: Intraepithelial CD8+ tumor-infiltrating lymphocytes and a high CD8+/regulatory T cell ratio are associated with favorable prognosis in ovarian cancer. Proc Natl Acad of Sci U S A 2005;102:18538-18543.

19 Yu H, Pardoll D, Jove R: STATs in cancer inflammation and immunity: a leading role for STAT3. Nat Rev Cancer 2009;9:798-809.

20 Yu H, Lee H, Herrmann A, Buettner R, Jove R: Revisiting STAT3 signalling in cancer: new and unexpected biological functions. Nat Rev Cancer 2014;14:736-746.

-21 Wilson RP, Ives ML, Rao G, Lau A, Payne K, Kobayashi M, Arkwright PD, Peake J, Wong M, Adelstein S, Smart JM, French MA, Fulcher DA, Picard C, Bustamante J, Boisson-Dupuis S, Gray P, Stepensky P, Warnatz K, Freeman AF et al.: STAT3 is a critical cell-intrinsic regulator of human unconventional T cell numbers and function. J Exp Med 2015;212:855-864.

-22 Yu H, Kortylewski M, Pardoll D: Crosstalk between cancer and immune cells: role of STAT3 in the tumour microenvironment. Nat Rev Immunol 2007;7:41-51.

23 Toh M-L, Kawashima M, Zrioual S, Hot A, Miossec P, Miossec P: IL-17 inhibits human Th1 differentiation through IL-12R $\beta 2$ downregulation. Cytokine 2009;48:226-230.

24 Liu Z, Huang Q, Liu G, Dang L, Chu D, Tao K, Wang W: Presence of FOXP3(+)Treg cells is correlated with colorectal cancer progression. Int J Clin Exp Med 2014;7:1781-1785.

25 Suzuki K, Kadota K, Sima CS, Nitadori J, Rusch VW, Travis WD, Sadelain M, Adusumilli PS: Clinical impact of immune microenvironment in stage I lung adenocarcinoma: tumor interleukin-12 receptor beta2 (IL12Rbeta2), IL-7R, and stromal FoxP3/CD3 ratio are independent predictors of recurrence. J Clin Oncol 2013;31:490-498.

-26 Yong-Deok K, Eun-Hyoung J, Yeon-Sun K, Kang-Mi P, Jin-Yong L, Sung-Hwan C, Tae-Yun K, Tae-Sung P, SoungMin K, Myung-Jin K, Jong-Ho L: Molecular genetic study of novel biomarkers for early diagnosis of oral squamous cell carcinoma. Med Oral Patol Oral Cir Bucal 2015;20:e167-179.

-27 Li J, Zhang L, Zhang J, Wei Y, Li K, Huang L, Zhang S, Gao B, Wang X, Lin P: Interleukin 23 regulates proliferation of lung cancer cells in a concentration-dependent way in association with the interleukin-23 receptor. Carcinogenesis 2013;34:658-666.

-28 Suzuki H, Ogawa H, Miura K, Haneda S, Watanabe K, Ohnuma S, Sasaki H, Sase T, Kimura S, Kajiwara T, Komura T, Toshima M, Matsuda Y, Shibata C, Sasaki I: IL-23 directly enhances the proliferative and invasive activities of colorectal carcinoma. Oncol Lett 2012;4:199-204.

29 Hu WH, Chen HH, Yen SL, Huang HY, Hsiao CC, Chuang JH: Increased expression of interleukin-23 associated with progression of colorectal cancer. J Surg Oncol 2017;115:208-212.

30 Fukuda M, Ehara M, Suzuki S, Sakashita H: Expression of interleukin-23 and its receptors in human squamous cell carcinoma of the oral cavity. Mol Med Rep 2010;3:89-93.

-31 Zhang XY, Zhang HJ, Zhang Y, Fu YJ, He J, Zhu LP, Wang SH, Liu L: Identification and expression analysis of alternatively spliced isoforms of human interleukin-23 receptor gene in normal lymphoid cells and selected tumor cells. Immunogenetics 2006;57:934-943. 


\section{Cellular Physiology Cell Physiol Biochem 2018;50:1041-1054 \begin{tabular}{ll|l} 
DOI: 10.1159/000494515 & $\begin{array}{l}\text { O } 2018 \text { The Author(s). Published by S. Karger AG, Basel } \\
\text { www.karger.com/cpb }\end{array}$ \\
\hline and Biochemistry Published online: 24 October 2018
\end{tabular}}

-32 Baird AM, Dockry E, Daly A, Stack E, Doherty DG, O’Byrne KJ, Gray SG: IL-23R is Epigenetically Regulated and Modulated by Chemotherapy in Non-Small Cell Lung Cancer. Front Oncol 2013;3:162.

-33 Langowski JL, Zhang X, Wu L, Mattson JD, Chen T, Smith K, Basham B, McClanahan T, Kastelein RA, Oft M: IL-23 promotes tumour incidence and growth. Nature 2006;442:461-465.

-34 Tao Y, Gross N, Liu Y, Zhang L, Li G, Huang Z, Yang J: A high ratio of IL-12Rß2-positive tumor-infiltrating lymphocytes indicates favorable prognosis in laryngeal cancer. Oral Oncol 2017;74:148-156.

-35 Hinni ML, Ferlito A, Brandwein-Gensler MS, Takes RP, Silver CE, Westra WH, Seethala RR, Rodrigo JP, Corry J, Bradford CR: Surgical margins in head and neck cancer: a contemporary review. Head Neck 2013;35:1362-1370.

-36 Figge J, Bakst G, Weisheit D, Solis O, Ross JS: Image analysis quantitation of immunoreactive retinoblastoma protein in human thyroid neoplasms with a streptavidin-biotin-peroxidase staining technique. Am J Pathol 1991;139:1213-1219.

-37 Rüdiger T, Höfler H, Kreipe H-H, Nizze H, Pfeifer U, Stein H, Dallenbach F, Fischer H-P, Mengel M, Von Wasielewski R: Quality assurance in immunohistochemistry: results of an interlaboratory trial involving 172 pathologists. Am J Pathol 2002;26:873-882.

38 Fedchenko N, Reifenrath J: Different approaches for interpretation and reporting of immunohistochemistry analysis results in the bone tissue-a review. Diagn Pathol 2014;9:221.

39 Salgado R, Denkert C, Demaria S, Sirtaine N, Klauschen F, Pruneri G, Wienert S, Van den Eynden G, Baehner FL, Penault-Llorca F: The evaluation of tumor-infiltrating lymphocytes (TILs) in breast cancer: recommendations by an International TILs Working Group 2014. Ann Oncol 2014;26:259-271.

-40 Jakobsson PÅ, Eneroth CM, Killander D, Moberger G, Mårtensson B: Histologic Classification and Grading of Malignancy in Carcinoma of the Larynx. Acta Radiol Ther Phys Biol 2009;12:1-8.

41 Luther SA, Cyster JG: Activated STAT Signaling in Human Tumors Provides Novel Molecular Targets for Therapeutic Intervention. Nat Immunol 2001;2:102-106.

-42 Kim Y, Lin Q, Glazer PM, Yun Z: Hypoxic Tumor Microenvironment and Cancer Cell Differentiation. Curr Mol Med 2009;9:425-434.

-43 Hill RP, Marie-Egyptienne DT, Hedley DW: Cancer stem cells, hypoxia and metastasis. Semin Radiat Oncol 2009;19:106-111.

44 Mohyeldin A, Garzon-Muvdi T, Quinones-Hinojosa A: Oxygen in stem cell biology: a critical component of the stem cell niche. Cell Stem Cell 2010;7:150-161.

45 Bending D, Newland S, Krejci A, Phillips JM, Bray S, Cooke A: Epigenetic changes at Il12rb2 and Tbx21 in relation to plasticity behavior of Th17 cells. J Immunol 2011;186:3373-3382.

46 Wilson CB, Rowell E, Sekimata M: Epigenetic control of T-helper-cell differentiation. Nat Rev Immunol 2009;9:91-105.

47 Yasmin R, Siraj S, Hassan A, Khan AR, Abbasi R, Ahmad N: Epigenetic regulation of inflammatory cytokines and associated genes in human malignancies. Mediators Inflamm 2015;2015:201703.

48 van Panhuys N, Le Gros G, McConnell MJ: Epigenetic regulation of Th2 cytokine expression in atopic diseases. Tissue Antigens 2008;72:91-97.

-49 Airoldi I, Cocco C, Di Carlo E, Disaro S, Ognio E, Basso G, Pistoia V: Methylation of the IL-12Rbeta2 gene as novel tumor escape mechanism for pediatric B-acute lymphoblastic leukemia cells. Cancer Res 2006;66:3978-3980. 